\title{
Insight into effects of Axillarin and Verbascoside isolated from Tanacetum alyssifolium and Plantago euphratica on probiotic properties of Lactobacillus acidophilus and Lactobacillus rhamnosus
}

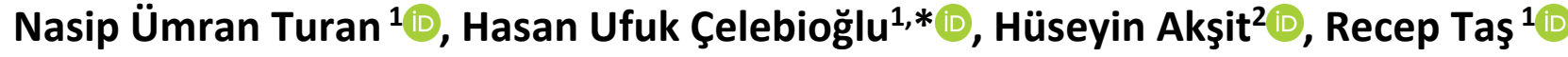 \\ ${ }^{1}$ Bartın University, Faculty of Science, Department of Biotechnology, 74110 Bartın, Turkey. \\ ${ }^{2}$ Erzincan Binali Yıldırım University, Faculty of Pharmacy, Department of Analytic Chemistry, 24100 Erzincan, Turkey
}

\author{
Article History \\ Received 16 May 2020 \\ Accepted 29 June 2020 \\ First Online 30 June 2020 \\ * Corresponding Author \\ Tel.: +90 5052417819 \\ E-mail: ufukcelebioglu@gmail.com
}

\section{Keywords}

Aggregation

MATS assay

Phenolic compounds

Probiotics

\begin{abstract}
Phenolic compounds are found in the seeds, flowers, leaves, stems, branches, and fruits of plants. They have an important place in human nutrition as many fruits and vegetables have phenolic compounds. Recently, many phenolic compounds have been used as functional foods and research of new phenolic compounds that are candidate to become functional foods is ongoing. Probiotics which are beneficial microorganisms, are living microbes that benefit the host when taken in sufficient amounts and they have an important role in human gastrointestinal microbiota. The present study aims to investigate effects of Axillarin and Verbascoside, two phenolic compounds isolated from Tanacetum alyssifolium and Plantago euphratica, respectively, on two very common probiotic bacteria Lactobacillus acidophilus and Lactobacillus rhamnosus. For this, growth kinetics, auto-aggregation, and microbial adhesion to solvents, which are some critical properties of probiotics, were investigated. Axillarin and verbascoside showed significant improvement on growths of Lactobacillus acidophilus LA-5 and Lactobacillus rhamnosus GG depending on the dose. Auto-aggregation properties were enhanced by these phenolic compounds, even though surface hydrophobicities were decreased. In conclusion, the present study indicates that the vital conditions of the probiotics could be modulated by Axillarin and/or Verbascoside, consequently their adhesion and colonization capabilities could be altered.
\end{abstract}

\section{Introduction}

Phenolic compounds are one of the highly studied topics for proving nature-based treatments. There are approximately 8000 phenolics present in plants, of which 4000 are elucidated (Bravo, 2009). Phenolic compounds are found in the seed flowers, leaves, stems, branches and fruits of plants. These compounds originated from pentose phosphate, shikimate, and phenylpropanoid pathways in plant metabolisms and are secondary metabolites in plants (Arceusz et al., 2013; Balasundram et al., 2006; Harborne et al., 1992; Silva et al., 2016). Phenolic compounds are effective in the growth, development, and the protection of plants against pathogenic organisms, giving taste and color properties to vegetables and fruits (Alasavar et al., 2001). These compounds, also called as polyphenols because of their structure, are found in many herbal foods and beverages, therefore they are present in significant amounts in human nutrition (Balasundram et al., 2006; Isavar et al., 2001). Polyphenols are thought to have many positive effects, including anti-allergic, antiviral, antioxidant, anti-mutagenic, anti-carcinogenic, anti-inflammatory, anti-microbial, and anti-thrombotic activities (Balasundram et al., 2006; Moure et al., 2001). The health benefits of phenolic compounds are mostly related to their antioxidant and anti-inflammatory properties. Although phenolic compounds do not have a direct nutritional value, only $5-10 \%$ are absorbed in the small intestine and $90-95 \%$ pass into the large intestine 
(Crozier et al., 2010). The compounds that interact directly with intestinal microflora may have positive or negative effects on these microorganisms (Cueva et al., 2017; Liano et al., 2016; Pereira-Caro et al., 2015). Probiotics are living microbes that benefit the host in sufficient amounts of practice and they have an important role in human nutrition and health. Such behavior of probiotics makes them functional foods that interact directly with gastrointestinal microflora (Arjmandi 2014; FAO, WHO 2006; Reuter 2001; Saarela et al., 2000). The most well-known probiotics belong to Lactobacillus genus. It is possible to find numerous studies regarding to modern-day Lactobacillus acidophilus and Lactobacillus rhamnosus. Lactobacilli are involved in human nutrition through their presence in milk and dairy products. Daily consumption of various types of food may alter the effects of probiotic bacteria on the intestinal system (Billoo et al., 2006; Kim et al., 2006; Lee \& Salminen, 1995; Salminen et al., 1998).

The reported antibacterial and antioxidant properties of phenolic compounds and how these compounds affect probiotic microorganisms that benefit their hosts, are among the topics that are still being investigated and discussed among the community today. Verbascoside, which was isolated from the Tanacetum alyssifolium for this research, is phenylethanoid glycoside, belonging to the phenylpropanoid family. The other phenolic compound is Axillarin which is an o-methylated flavanol belonging to the Flavonoid group isolated from the Plantago euphratica. Previous studies on the phenolic compounds of Verbascoside and Axillarin (Figure 1) have been studied on their antioxidant and anti-inflammatory effects (Georgiev et al. 2012; Hu et al. 2017). Therefore, the present study aimed to elucidate the effects of these polyphenol compounds on probiotics microorganisms, Lactobacillus acidophilus and Lactobacillus rhamnosus.

\section{Materials and Methods}

\section{Isolation of Axillarin}

$20 \mathrm{~g}$ of methanolic extract of Tanacetum alyssifolium was firstly fractioned over sephadex $\mathrm{LH}-20$ using methanol as a mobile phase. According to the thinlayer chromatography (TLC) basis, Axillarin containing fractions (1.2 g) were combined and separated over C18 packed column. Water and methanol mixture were used as follows: 100:0, 80:20, 70:30 and 60:40 (v:v) each 0.5 L. Axillarin was obtained from fractions eluted with 60:40 water: methanol (v:v) system. The solvents were evaporated to dryness to give $875 \mathrm{mg}$ of Axillarin.

\section{Isolation of Verbascoside}

Ten grams (10 g) of methanolic extract of Plantago euphratica was dissolved in hot water, then kept at $+4^{\circ} \mathrm{C}$ overnight and non-soluble parts were removed by filtration. The water extract was lyophilized to give $4 \mathrm{~g}$ of pale-yellow solid. One gram (1 g) portion of extract was dissolved in $20 \mathrm{~mL}$ deionized water and repeatedly injected to HPLC ten times using $2 \mathrm{~mL}$ sample loop. The HPLC system used was a Shimadzu Prep-HPLC instrument with recycling mode equipped with LC20AR pump, SPD-20A UV-Vis detector and FRC-10A fraction collector. The mobile phase was a mixture of deionized water/acetonitrile (ACN); the UV wavelengths were 235 and $280 \mathrm{~nm}$. The preparative column $(250 \times 20 \mathrm{~mm}, 10$ $\mu \mathrm{m})$ used was C18 (EMR Chrometsil). The flow rate was $8 \mathrm{~mL} / \mathrm{min}$. Verbascoside was purified from crude extract using a gradient elution from 90:10 to 50:50 (water: ACN) with $8 \mathrm{~mL} / \mathrm{min}$ flow rate. The main peaks were collected according to the absorbance at 235 and 230 $\mathrm{nm}$. Each collected fraction was purified using recycling mode with isocratic elution with 85:15 (Water: ACN), with $8 \mathrm{~mL} / \mathrm{min}$ flow rate. The recycling process was continued until a clear separation was observed.

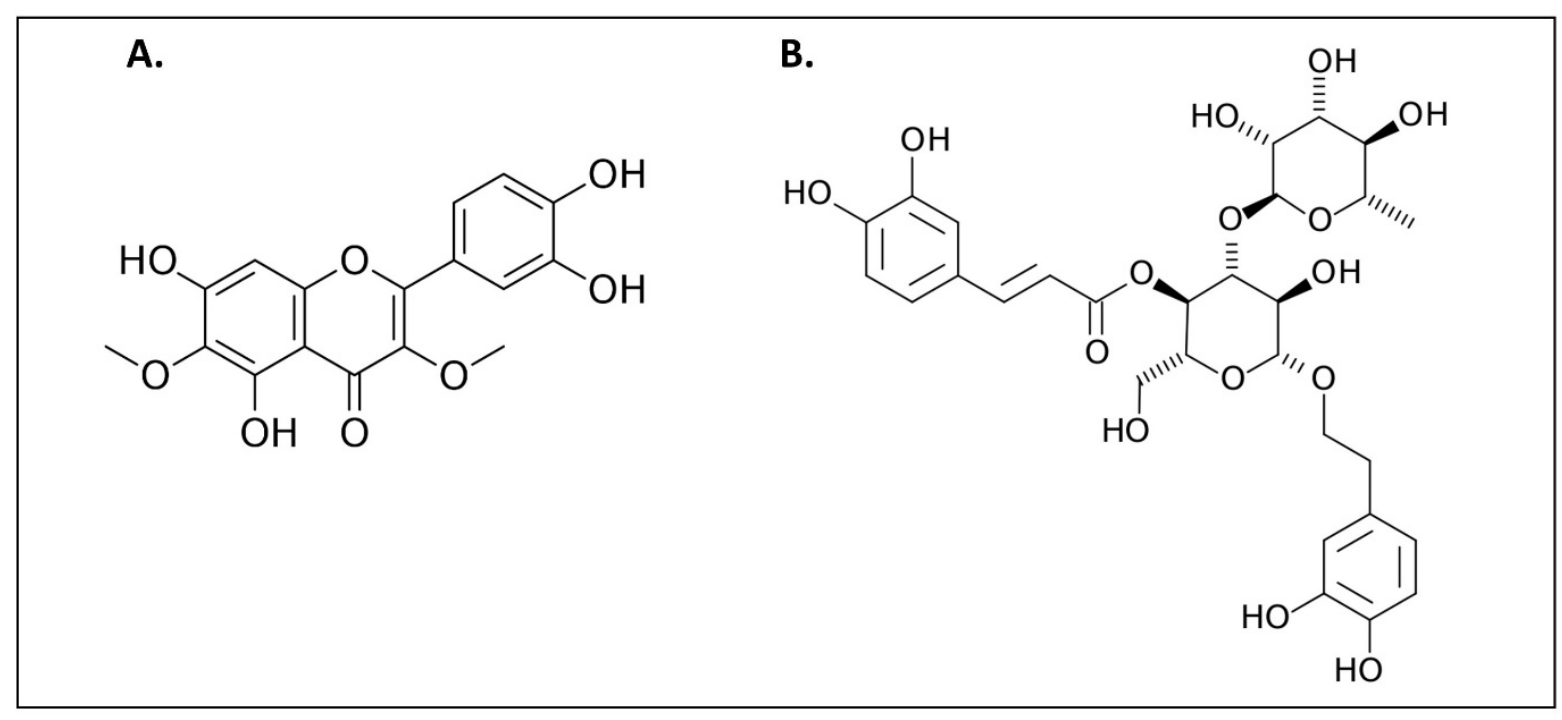

Figure 1. Chemical structures of (A) Axillarin and (B) Verbascoside. 
${ }^{1} \mathrm{H}$ and ${ }^{13} \mathrm{C}$ NMR spectra were recorded on 400 $\mathrm{MHz}$ and $600 \mathrm{MHz}$, respectively (Bruker). Chemical shifts were in ppm from $\mathrm{Me}_{4} \mathrm{Si}$, generated from MeOD.

Growth of probiotic bacteria in the presence of Axillarin and Verbascoside, and their bacterial growth kinetics

Lactobacillus acidophilus LA-5 and Lactobacillus rhamnosus GG, kindly provided from Chr. Hansen, Turkey, were grown in Man, Rogosa and Sharpe (MRS) medium without shaking, at $37{ }^{\circ} \mathrm{C}$ (Celebioglu et al., 2018). The bacteria were treated separately with Axillarin and Verbascoside, not in mixture and Axillarin and Verbascoside were not added to the control groups (MRS only). Two different experiments were prepared for Axillarin and Verbascoside under the same conditions, and $5 \mu \mathrm{g} / \mathrm{mL}, 10 \mu \mathrm{g} / \mathrm{mL}$ and $12.5 \mu \mathrm{g} / \mathrm{mL}$ Axillarin and Verbascoside were added to bacterial growth media for each treatment groups. Bacterial optical density measurements were determined every four-hours with McFarland tube densitometer (BuchHolm).

\section{Probiotic auto-aggregation}

Bacterial cells were incubated for 16 hours by treatment with Axillarin and Verbascoside, harvested in stationary phase $(3200 \mathrm{~g}, 15 \mathrm{~min})$, washed with Phosphate-saline buffer (PBS) and re-suspended in PBS to $\mathrm{OD}_{600} 0.5$ (Kos et al., 2003). The percentage of autoaggregation is calculated according to equation 1 ;

$$
\text { Auto-Aggregation } \%=\left(1-\frac{A t}{A 0}\right) \times 100
$$

where $A_{t}$ is the absorbance measured after incubation and $A_{0}$ is the absorbance measured at $0^{\text {th }}$ hour (Kos et al., 2003).

\section{Microbial adhesion to solvent (MATS)}

Microbial adhesions of probiotic bacteria to solvents were measured by using the method described previously in the study of Kos et al. (2003). After growing, harvesting, and washing the bacterial cells as described above, they were suspended with $0.1 \mathrm{M} \mathrm{KNO}_{3}$ $\left(\mathrm{pH}\right.$ 6.2) to have $\mathrm{OD}_{600}$ of 0.5 . One $\mathrm{mL}$ of Xylene (nonpolar solvent) was added to $3 \mathrm{~mL}$ of bacterial suspension and incubated at room temperature (RT) for $10 \mathrm{~min}$ then the two-phase system was vortexed for $2 \mathrm{~min}$, the aqueous phase was separated and incubated again for $20 \mathrm{~min}$ at RT. Absorbance was measured at $600 \mathrm{~nm}$ and bacterial adhesion solvent was calculated according to equation 2;

$$
\text { Adhesion } \%=1-\left(\frac{A 1}{A 0}\right) \times 100
$$

where, $A_{1}$ is the absorbance measured after the incubation and $A_{0}$ is the absorbance measured before the incubation (Kos et al., 2003).

\section{Statistical analysis}

Each experiment was designed as three biological replicates, and measurements were repeated three times. Results of measurements were expressed as mean \pm standard deviation and One-way ANOVA was used to evaluate the results using GraphPad Prism version 8.0. Differences were considered as significant for $p<0.05$.

\section{Results and Discussion}

\section{NMR assay of Axillarin}

${ }^{1} \mathrm{H}$ NMR $(600 \mathrm{MHz}, \mathrm{MeOD}) \delta_{\mathrm{H}} 7.61(\mathrm{~s}, 1 \mathrm{H}), 7.52(\mathrm{~d}$, $J=8.0 \mathrm{~Hz}, 1 \mathrm{H}), 6.89(\mathrm{~d}, J=8.0 \mathrm{~Hz}, 1 \mathrm{H}), 6.48(\mathrm{~s}, 1 \mathrm{H}), 4.84$ (brs, $4 \mathrm{H},-\mathrm{OH}), 3.87\left(\mathrm{~s}, 3 \mathrm{H},-\mathrm{OCH}_{3}\right), 3.78\left(\mathrm{~s}, 3 \mathrm{H},-\mathrm{OCH}_{3}\right)$. ${ }^{13} \mathrm{C}$ NMR (150 MHz, MeOD) $\delta_{\mathrm{c}} 178.8$ (C-4),157.4 (C-7), 156.7 (C-2), 152.3 (C-5), 152.2 (C-9), 148.5 (C-4'), 145.0 (C-3'), 137.8 (C-3), 131.2 (C-6), 121.5 (C-1'), $120.9\left(C-6^{\prime}\right)$, 115.1 (C-5'), 115.0 (C-2'), 104.9 (C-10), 93.6 (C-8),59.5 $\left(\mathrm{C}-6-\mathrm{OCH}_{3}\right), 59.1\left(\mathrm{C}-3-\mathrm{OCH}_{3}\right)$.

\section{NMR assay of Verbascoside}

${ }^{1} \mathrm{H}$ NMR $(400 \mathrm{MHz}, \mathrm{MeOD}) \delta_{\mathrm{H}} 7.62(\mathrm{~d}, \mathrm{~J}=15.87,1 \mathrm{H}$, $\left.H \beta^{\prime}\right), 7.08\left(d, J=2.12,1 H, H 2^{\prime}\right), 6.98(d d, J=8.21,2.12,1 H$, $\left.H 6^{\prime}\right), 6.80\left(\mathrm{~d}, \mathrm{~J}=8.09,1 \mathrm{H}, \mathrm{H} 5^{\prime}\right), 6.72(\mathrm{~d}, \mathrm{~J}=2.09,1 \mathrm{H}, \mathrm{H} 2$ ), 6.70 (d, J=7.91, 1H, H5), 6.59 (dd, J=8.00, 2.14, 1H, H6), $6.30\left(\mathrm{~d}, \mathrm{~J}=15.88,1 \mathrm{H}, \mathrm{H \alpha} \mathrm{\prime}^{\prime}\right), 5.21$ (d, J=1.83, 1H, H1'"'), 4.94 (m, 1H, H4"), 4.40 (d, J=7.86, 1H, H1"), 4.07 (dt, J=9.71, 7.32, 1H, Haa), 3.94 (m, 1H, H2'"'), 3.84 (t, J=9.20, 1H, $H 3 "), 3.74(m, 1 H, H \alpha b), 3.65(m, 1 H, H 6 " a), 3.61(m, 1 H$, $\left.\mathrm{H}^{\prime \prime \prime}\right), 3.58\left(\mathrm{~m}, 1 \mathrm{H}, \mathrm{H} 5^{\prime \prime}\right), 3.56\left(\mathrm{~m}, 1 \mathrm{H}, \mathrm{H} 5^{\prime \prime}\right), 3.54(\mathrm{~m}, 1 \mathrm{H}$, H6"b), 3.41 (t, J=8.48, 1H, H2"), 3.32 (m, 1H, H4'"'), 2.81 (dt, J=7.35, 2.45, 2H, HB), 1.11 (d, J=6.21, 3H, H6"'). ${ }^{13} \mathrm{C}$ NMR (101 MHz, MeOD) $\delta_{\mathrm{C}} 166.93$ (C=0), 148.38 (C4'), $146.63\left(C \beta^{\prime}\right), 145.43\left({ }^{\prime} 3^{\prime}\right), 144.74$ (C3), 143.28 (C4), 130.15 (C1), 126.32 (C1'), 121.83 (C6'), 119.91 (C6), 115.76 (C2), 115.17 (C5'), 114.96 (C5), 113.91 (C2'), 113.37 (Ca'), 102.83 (C1"), 101.63 (C1'"), 80.27 (C3"), 74.83 (C2"), 74.65 (C5"),

NMR assignments were fully agreed with literature for Verbascoside and Axillarin (Akdemir et al., 2004). Verbascoside is a common phenyl ethanoid for Plantago species and was previously isolated from $P$. lagopus (Harput et al., 2012), P. pellardii (Gálvez et al., 2005), and P. cynops (Debrauwer et al., 1989).

\section{Bacterial growth kinetics}

In this study, Axillarin and Verbascoside were used in concentrations of 5,10 and $12.5 \mu \mathrm{g} / \mathrm{mL}$. The groups treated with Axillarin and Verbascoside showed significant improvement on Lactobacillus acidophilus LA-5 and Lactobacillus rhamnosus GG depending on the dose of phenolic compounds, when compared with control groups (Figure 2). Previous studies have examined the antimicrobial effect of Axillarin and found that it inhibited the development of pathogenic bacteria (Avila et al., 1999). However, in the present study, Verbascoside have positively influenced growth of Lactobacillus acidophilus and Lactobacillus rhamnosus. 


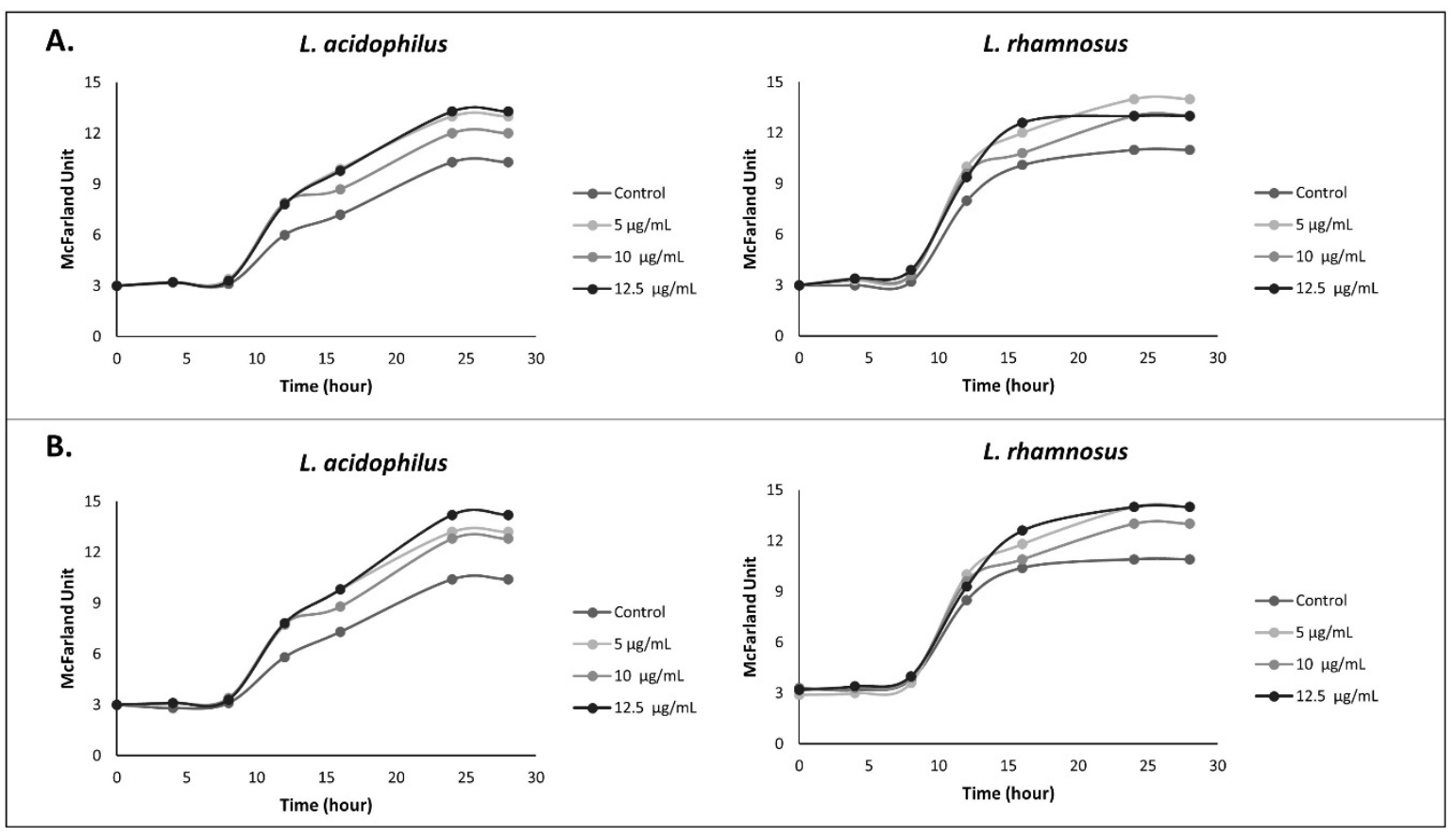

Figure 2. Growth kinetics of probiotic bacteria. (A) Growth curve of Lactobacillus acidophilus LA-5 and Lactobacillus rhamnosus GG when grown in the presence of Axillarin. (B) Growth curve of Lactobacillus acidophilus LA-5 and Lactobacillus rhamnosus GG when grown in the presence of Verbascoside.

Anti-inflammatory effect studies have also been reported for Axillarin, but on Lactobacillus acidophilus LA-5 and Lactobacillus rhamnosus GG have shown an effect that promoted development (Beg et al., 2011). The fact that these compounds have no antimicrobial effects on Lactobacillus acidophilus and Lactobacillus rhamnosus suggests that they have the potential to have selectively positive effects on beneficial bacteria in the intestinal microflora.

\section{Bacterial auto-aggregation}

Even though there are many protective mechanisms present in the gastrointestinal mucosa, humans are occasionally exposed to enteric pathogens.
Enteric pathogens cause infection by colonizing on microflora present in the gastrointestinal tract (Sekirov et al., 2010). Therefore, adhesion to intestinal epithelial cells is a prerequisite for colonizing probiotic strains in the gastrointestinal tract, preventing their immediate elimination (Alander et al., 1997; Freter 1992; Pedersen and Tannock 1989). Consequently, auto-aggregation is an important condition for the adhesion and survival of probiotic strains to the intestinal epithelium (Boris et al., 1997; Del Re et al., 1998). The concentration of $5 \mu \mathrm{g} / \mathrm{mL}$ of Axillarin significantly decreased the auto-aggregation of Lactobacillus acidophilus at $1^{\text {st }}$ hour, then the next hours of the auto-aggregation, it significantly $(p<0.05)$ increased the auto-aggregation, when compared to

Table 1. Auto-aggregation percentages of probiotics grown in the presence of Axillarin. The results are given as mean with standard deviations. Asterisks $\left({ }^{*}\right)$ indicate the differences are statistically significant $(p<0.05)$ when compared to respective control groups, according to One-Way ANOVA.

\begin{tabular}{|c|c|c|c|c|c|}
\hline & $1^{\text {st }}$ Hour & $2^{\text {nd }}$ Hour & $3^{\text {rd }}$ Hour & $4^{\text {th }}$ Hour & $5^{\text {th }}$ Hour \\
\hline & \multicolumn{5}{|c|}{ L. acidophilus } \\
\hline Control & $59.2 \pm 0.6$ & $21.8 \pm 0.7$ & $59.7 \pm 13.0$ & $70.4 \pm 17.6$ & $83.8 \pm 9.5$ \\
\hline $5 \mu \mathrm{g} / \mathrm{mL}$ & $20.5 \pm 1.4 *$ & $42.7 \pm 1.3 *$ & $70.4 \pm 4.5 *$ & $79.1 \pm 1.5 *$ & $81.6 \pm 0.7$ \\
\hline $10 \mu \mathrm{g} / \mathrm{mL}$ & $21.8 \pm 0.3 *$ & $65.0 \pm 0.2 *$ & $70.1 \pm 0.3 *$ & $72.1 \pm 0.5$ & $84.1 \pm 7.0$ \\
\hline \multirow[t]{2}{*}{$12.5 \mu \mathrm{g} / \mathrm{mL}$} & $29.6 \pm 0.2 *$ & $32.9 \pm 0.1 *$ & $64.2 \pm 3.8$ & $79.8 \pm 2.0 *$ & $87.4 \pm 6.1 *$ \\
\hline & \multicolumn{5}{|c|}{ L. rhamnosus } \\
\hline Control & $84.5 \pm 2.6$ & N.D. & N.D. & N.D. & N.D. \\
\hline $5 \mu \mathrm{g} / \mathrm{mL}$ & $84.3 \pm 2.4$ & N.D. & N.D. & N.D. & N.D. \\
\hline $10 \mu \mathrm{g} / \mathrm{mL}$ & $88.7 \pm 5.2 *$ & N.D. & N.D. & N.D. & N.D. \\
\hline $12.5 \mu \mathrm{g} / \mathrm{mL}$ & $89.1 \pm 3.0 *$ & N.D. & N.D. & N.D. & N.D. \\
\hline
\end{tabular}


control (Table 1). The second concentration is $10 \mu \mathrm{g} / \mathrm{mL}$ and showed a significant decrease at $1^{\text {st }}$ hour, but at $2^{\text {nd }}$ and $3^{\text {rd }}$ hour, it increased the auto-aggregation, compared to control group. The last concentration is $12.5 \mu \mathrm{g} / \mathrm{mL}$ and showed a significant decrease in the first two hours but increase in auto-aggregation in the last hours. This could mean Axillarin has a positive effect on auto-aggregation of Lactobacillus acidophilus. On the other hand, the auto-aggregation of Lactobacillus rhamnosus was significantly increased by $10 \mu \mathrm{g} / \mathrm{mL}$ and $12.5 \mu \mathrm{g} / \mathrm{mL}$ of Axillarin in the first hour as compared to control group. In the next hours of the assay, the autoaggregation was reached to the maximum, which means the comparison and measurement were not possible (stated in the table as ND). The results of autoaggregation indicate that these polyphenols can positively affect the adhesion of the probiotic bacteria as auto-aggregation which is very important for probiotic microorganisms to adhesion and live in the gastrointestinal tract (GIT) (Boris et al., 1997; Del Re et al., 1998).

Auto-aggregation of Verbascoside showed a significant decrease $(p<0.05)$ in auto-aggregation of $L$. acidophilus at the concentration of $5 \mu \mathrm{g} / \mathrm{mL}$ in the $1^{\text {st }}$ and $2^{\text {nd }}$ hours as compared with control groups; however, increase in the $5^{\text {th }}$ hour (Table 2). The concentration of $10 \mu \mathrm{g} / \mathrm{mL}$ showed an important decrease in auto-aggregation in the $1^{\text {st }}$ and $2^{\text {nd }}$, but significantly increased in the $3^{\text {rd }}$ and $5^{\text {th }}$ hours. The concentration of $12.5 \mu \mathrm{g} / \mathrm{mL}$ significantly decreased auto-aggregation in the $2^{\text {nd }}$ and there are significantly increases at $3^{\text {rd }}, 4^{\text {th }}$, and $5^{\text {th }}$ hours when compared with control group. On the other hand, auto-aggregation of Lactobacillus rhamnosus was significantly increased by Verbascoside with every concentration. In the next hours of measurements, the auto-aggregations were not able to be obtained, which means there were no bacteria found on the surface of suspension because they were aggregating completely down to the tubes (Table 2).

Auto-aggregation of probiotics grown in the presence of phenolic compounds was mostly lower than the control group at $1^{\text {st }}$ hour. This could be explained by that bacteria started interacting each other at the beginning and after one hour, these interactions could not be fully achieved. Thus, in time, bacteria could interact fully, and the effects of phenolic compounds could be observed at the later hours. Increased autoaggregation, at later hours, can indicate these beneficial bacteria are positively affected by Axillarin and Verbascoside, thus they have potential to adhere more in the GIT and show their probiotic activities to the host (Boris et al., 1997; Del Re et al., 1998).

\section{Microbial adhesion to solvents (MATS)}

The surface properties of Lactobacilli contribute to their interactions with the host and gastrointestinal microbiota. Thus, this can affect their residence in GIT by allowing Lactobacilli adhering to intestinal tissue, as well as affecting interactions with their own species and other bacteria (Kleerebezem et al., 2010; Lebeer et al., 2008). The adhesion behavior of microbial cells has been shown to depend on the van der Waals interactions and balance of electrostatic on the hydrophobic character of the surfaces (Boonaert \& Rouxhet 2000). Hydrophobicity plays an important role for the contact between a bacterial cell and mucous or epithelial cell (Schillinger et al., 2005). In this assay, Xylene (non-polar solvent) was used to assess the hydrophobic and hydrophilic characteristics of bacterial surface (Bellon-Fontaine et al., 1996; Kos et al., 2003). As a result of the assays conducted, surface hydrophobicity of both bacteria was significantly $(p<0.05)$ decreased by presence of Axillarin and Verbascoside at every concentration, as compared to control (Figure 3).

Table 2. Auto-aggregation percentages of probiotics grown in the presence of Verbascoside. The results are given as mean with standard deviations. Asterisks $(*)$ indicate the differences are statistically significant $(p<0.05)$ when compared to respective control groups, according to One-Way ANOVA applied for each column.

\begin{tabular}{|c|c|c|c|c|c|}
\hline & $1^{\text {st }}$ Hour & $2^{\text {nd }}$ Hour & $3^{\text {rd }}$ Hour & $4^{\text {th }}$ Hour & $5^{\text {th }}$ Hour \\
\hline & \multicolumn{5}{|c|}{ L. acidophilus } \\
\hline Control & $31.4 \pm 12.2$ & $47.5 \pm 13.2$ & $47.4 \pm 1.1$ & $69.7 \pm 7.9$ & $64.5 \pm 3.6$ \\
\hline $5 \mu \mathrm{g} / \mathrm{mL}$ & $23.1 \pm 7.9 *$ & $17.1 \pm 4.8 *$ & $49.3 \pm 1.9$ & $63.2 \pm 5.3$ & $71.5 \pm 0.5 *$ \\
\hline $10 \mu \mathrm{g} / \mathrm{mL}$ & $28.0 \pm 2.3 *$ & $11.6 \pm 1.3 *$ & $61.8 \pm 0.2 *$ & $68.2 \pm 0.7$ & $77.0 \pm 10.1 *$ \\
\hline \multirow[t]{2}{*}{$12.5 \mu \mathrm{g} / \mathrm{mL}$} & $30.4 \pm 0.9$ & $34.6 \pm 6.9 *$ & $65.0 \pm 14.6 *$ & $72.9 \pm 0.1 *$ & $62.7 \pm 0.6$ \\
\hline & \multicolumn{5}{|c|}{ L. rhamnosus } \\
\hline Control & $65.8 \pm 2.1$ & N.D. & N.D. & N.D. & N.D. \\
\hline $5 \mu \mathrm{g} / \mathrm{mL}$ & $80.5 \pm 13.4 *$ & N.D. & N.D. & N.D. & N.D. \\
\hline $10 \mu \mathrm{g} / \mathrm{mL}$ & $84.6 \pm 13.0 *$ & N.D. & N.D. & N.D. & N.D. \\
\hline $12.5 \mu \mathrm{g} / \mathrm{mL}$ & $81.0 \pm 0.6^{*}$ & N.D. & N.D. & N.D. & N.D. \\
\hline
\end{tabular}

N.D.: Not Determined 


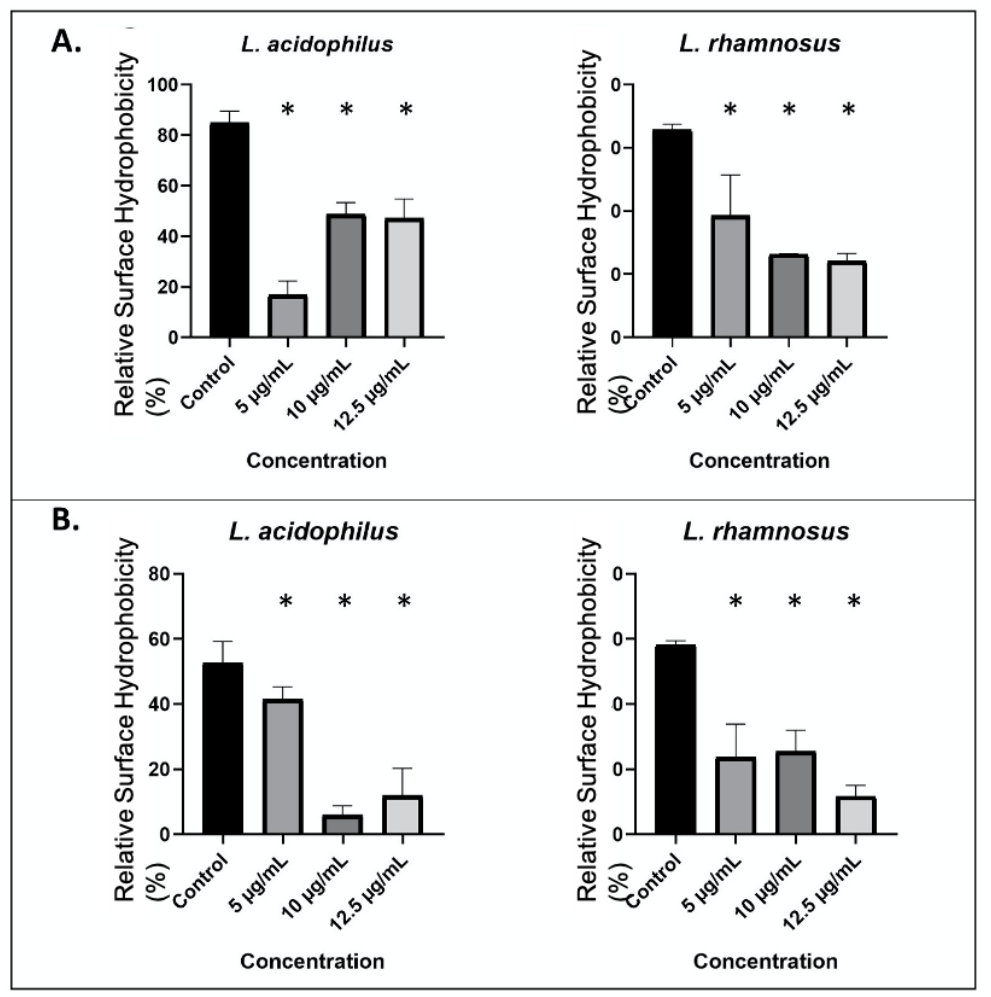

Figure 3. Surface hydrophobicity (A) of Lactobacillus acidophilus LA-5 and Lactobacillus rhamnosus GG when grown in the presence of Axillarin and (B) of Lactobacillus acidophilus LA-5 and Lactobacillus rhamnosus $\mathrm{GG}$ when grown in the presence of Verbascoside. Asterisks $(*)$ indicate the differences are statistically significant $(p<0.05)$ when compared to respective control groups, according to One-Way ANOVA.

Lactobacillus may well serve as model systems for the study of structure-property functions of the bacterial cell envelope (Schär-Zammaretti \& Ubbink 2003). Physicochemical properties of the cell surface, such as hydrophobicity, can affect the automatic aggregation and adhesion of bacteria to different surfaces. Cell adhesion is a complex process involving contact between bacterial cell membrane and interacting surfaces (Del Re et al., 1998; Perez et al., 1998; Wadström et al., 1987). On this topic, reported investigations were on the structure and forces of interaction and composition related to bacterial adhesion to intestinal epithelial cells (Del Re et al., 1998; Perez et al., 1998) and mucus (Collado et al., 2005). However, in addition to surface properties of the bacteria, the surface proteins that many lactobacilli possess, specifically S-layer proteins binding to the cell wall in a non-covalent manner, play significant roles in adhesion (Celebioglu \& Svensson, 2017). The biological functions of the S-layer include protection, determination of cell shape, molecular and ion capture to surfaces where adhesion takes place. It is thought that the structure responsible for the attachment of a bacterial cell to the intestinal epithelium is the S-layer (Meng et al., 2017; Wasko et al., 2014). Therefore, not only hydrophobicity and aggregation are sufficient for good adhesion ability, but more importantly, surface proteins of bacteria play a key role on bacterial adhesion (Schär-Zammaretti \& Ubbink 2003; Sengupta et al., 2013).

\section{Conclusion}

In the present study, growth kinetics, autoaggregation, and microbial adhesion to solvents assays were tested using Axillarin and Verbascoside polyphenols on probiotics, which are beneficial microorganisms to the host (Lactobacillus acidophilus LA-5 and Lactobacillus rhamnosus GG). Probiotic bacteria tested here, treated with Axillarin and Verbascoside polyphenols, showed significant alterations in auto-aggregation and hydrophobicity experiments. The results from the auto-aggregation and hydrophobicity (MATS) experiments indicate that the vital conditions of the probiotics could be modulated by Axillarin and/or Verbascoside, consequently alter their adhesion and colonization capabilities. Furthermore, future studies could investigate how polyphenols affect the surface proteins of probiotic bacteria, which are of great importance for bacterial adhesion.

\section{References}

Akdemir, Z. Ş., Tatli, I. I., Bedir, E., \& Khan, I. A. (2004). Iridoid and phenylethanoid glycosides from Verbascum lasianthum. Turkish Journal of Chemistry, 28(2), 227234.

Alasalvar, C., Grigor, J. M., Zhang, D., Quantick, P. C., \& Shahidi, F. (2001). Comparison of Volatiles, Phenolics, Sugars, Antioxidant Vitamins, and Sensory Quality of Different Colored Carrot Varieties. Journal of Agricultural and Food Chemistry, 49(3), 1410-1416. 
Alander, M., Korpela, R., Saxelin, M., Vilpponen-Salmela, T., Matilla-Sandholm, T., \& Wright, A. (1997). Recovery of Lactobacillus rhamnosus GG from human colonic biopsies. Letters in Applied Microbiology, 24, 361-364.

Arceusz, A., Wesolowski, M., \& Konieczynski, P. (2013). Methods for Extraction and Determination of Phenolic Acids in Medicinal Plants: A Review. Natural Product Communications, 8(12), 1821-29.

Arjmandi, B. H. (2014). The Role of Prebiotics and Probiotics in Human Health. Journal of Food \& Nutritional Disorders, 1(2), 108.

Avila, J. G., de Liverant, J. G., Martınez, A., Martınez, G., Munoz, J. L., Arciniegas, A., \& de Vivar, A. R. (1999). Mode of action of Buddleja cordata verbascoside against Staphylococcus Ethnopharmacology, 66(1), 75-78.

Balasundram, N., Sundram, K., \& Samman, S. (2006). Phenolic compounds in plants and agri-industrial by-products: Antioxidant activity, occurrence, and potential uses. Food Chemistry, 99(1), 191-203.

Bellon-Fontaine, M.-N., Rault, J., \& van Oss, C.J. (1996) Microbial adhesion to solvents: a novel method to determine the electron-donor/ electron-acceptor or Lewis acid-base properties of microbial cells. Colloid Surface B, 7, 47-53.

Beg, S., Swain, S., Hasan, H., Barkat, M. A., \& Hussain, M. S. (2011). Systematic review of herbals as potential antiinflammatory agents: Recent advances, current clinical status and future perspectives. Pharmacognosy Reviews, 5(10), 120.

Billoo, A. (2006). Role of a probiotic (Saccharomyces boulardii) in management and prevention of diarrhoea. World Journal of Gastroenterology, 12(28), 4557.

Boonaert, C. J. P., \& Rouxhet, P. G. (2000). Surface of lactic acid bacteria: Relationships between chemical composition and physicochemical properties. Applied and Environmental Microbiology, 66(6), 2548-2554.

Boris S, Suarez J. E, \& Barbes C. (1997). Characterization of the aggregation promoting factor from Lactobacillus gasseria vaginal isolate. Journal of Applied Microbiology, 83(4), 413- 420.

Bravo, L. (2009). Polyphenols: Chemistry, Dietary Sources, Metabolism, and Nutritional Significance. Nutrition Reviews, 56(11), 317-333.

Celebioglu, H. U., \& Svensson, B. (2017). Exo- and Surface proteomes of the probiotic bacterium Lactobacillus acidophilus NCFM. Proteomics, 17(11), 1700019.

Celebioglu, H. U., Delsoglio, M., Brix, S., Pessione, E., \& Svensson, B. (2018). Plant polyphenols stimulate adhesion to intestinal mucosa and induce proteome changes in the probiotic Lactobacillus acidophilus NCFM. Molecular Nutrition and Food Research, 62(4), 1700638.

Crozier, A., Del Rio, D., \& Clifford, M. N. (2010). Bioavailability of dietary flavonoids and phenolic compounds. Molecular Aspects of Medicine, 31(6), 446-467.

Cueva, C., Gil-Sánchez, I., Ayuda-Durán, B., GonzálezManzano, S., González-Paramás, A., Santos-Buelga, C., Bartolomé, B., \& Moreno-Arribas, M. (2017). An Integrated View of the Effects of Wine Polyphenols and Their Relevant Metabolites on Gut and Host Health. Molecules, 22(1), 99.

Collado, M. C., Gueimonde, M., Hemandez, M., Sanz, Y., \& Salminen, S. (2005). Adhesion of selected Bifidobacterium strains to human intestinal mucus and the role of adhesion in enteropathogen exclusion. Journal of Food Protection, 68(12), 26722678.

Debrauwer, L., Maillard, C., Babadjamian, A., Vidal-Ollivier, E., Laget, M., Salmona, G., \& Afzal-Raffi, Z. (1989). Study in the chemical constituents of Plantago cynops L. and antibacterial evaluation of verbascoside. Pharmaceutica Acta Helvetiae, 64(7), 183-187.

Del Re, B., Busetto, A., Vignola, G., Sgorbati, B., \& Palenzona, D. (1998). Autoaggregation and adhesion ability in a Bifidobacterium suis strain. Letters in Applied Microbiology, 27, 307-310.

FAO/WHO. (2006). Probiotics in food-health and nutritional properties and guidelines for evaluation. FAO Food Nutrition Paper, 85.

Freter, M. (1992). Factors affecting the microecology of the gut In Probiotics. The Scientific Basis ed. Fuller, R. pp. 111145. Glasgow: Chapman \& Hall.

Gálvez, M., Martín-Cordero, C., Houghton, P. J., \& Ayuso, M. J. (2005). Antioxidant activity of methanol extracts obtained from Plantago species. Journal of Agricultural and Food Chemistry, 53(6), 1927-1933.

Harborne, J. B., \& Williams, C. A. (2000). Advances in flavonoid research since 1992. Phytochemistry, 55(6), 481-504.

Harput, U. S., Genc, Y., \& Saracoglu, I. (2012). Cytotoxic and antioxidative activities of Plantago lagopus $L$. and characterization of its bioactive compounds. Food and chemical toxicology, 50(5), 1554-1559.

He, F., Ouwehand, A. C., Isolauri, E., Hosoda, M., Benno, Y., \& Salminen, S. (2001). Differences In Composition And Mucosal Adhesion of Bifidobacteria Isolated From Healthy Adults And Healthy Seniors. Current Microbiology, 43, 351-354.

Hu, J., Ma, W., Li, N., \& Wang, K.-J. (2018). Antioxidant and Anti-Inflammatory Flavonoids from the Flowers of Chuju, a Medical Cultivar of Chrysanthemum Morifolim Ramat. Journal of the Mexican Chemical Society, 61(4), 282-289.

Kim, H. S., Park, H., Cho, I. Y., Paik, H. D., \& Park, E. (2006). Dietary Supplementation of Probiotic Bacillus polyfermenticus, Bispan Strain, Modulates Natural Killer Cell and T Cell Subset Populations and Immunoglobulin $G$ Levels in Human Subjects. Journal of Medicinal Food, 9(3), 321-327.

Kleerebezem, M., Hols, P., Bernard, E., Rolain, T., \& Zhou, M. (2010). The extracellular biology of the lactobacilli. FEMS Microbiology Reviews, 34, 199-230.

Kos, B., Suskovic, J., Vukovic, S., Simpraga, M., Frece, J., \& Matosic, S. (2003) Adhesion and aggregation ability of probiotic strain Lactobacillus acidophilus M29. Journal of Applied Microbiology, 94, 981-987.

Lebeer, S., Verhoeven, T. L. A., Francius, G., Schoofs, G., Lambrichts, I., Dufre^ne, Y., Vanderleyden, J., \& Keersmaecker, S. C. J. (2009). Identification of a gene cluster for the biosynthesis of a long, galactose-rich exopolysaccharide in Lactobacillus rhamnosus $G G$ and functional analysis of the priming glycosyltransferase. Applied and Environmental Microbiology, 72, 728-764.

Llano, D. G. D., Gil-Sánchez, I., Esteban-Fernández, A., Ramos, A. M., Fernández-Díaz, M., Cueva, C., \& Bartolomé, B. (2016). Reciprocal beneficial effects between wine polyphenols and probiotics: an exploratory study. European Food Research and Technology, 243(3), 531-538. 
Moure, A., Cruz, J. M., Franco, D., Domínguez, J. M., Sineiro, J., Domínguez, H., \& Parajó, J. (2001). Natural antioxidants from residual sources. Food Chemistry, 72(2), 145-171.

Pedersen, K., \& Tannock, G. W. (1989). Colonization of the porcine gastrointestinal tract by lactobacilli. Applied and Environmental Microbiology, 55, 279-283.

Pérez, P. F., Minnaard, Y., Disalvo, E. A., \& De Antoni, G. L. (1998). Surface properties of bifidobacterial strains of human origin. Applied and Environmental Microbiology, 64, 21-26.

Reuter, G. (2001). The Lactobacillus and Bifidobacterium microflora of the human intestine: composition and succession. Current issues in intestinal microbiology, 2(2), 43-53.

Saarela, M., Mogensen, G., Fondén, R., Mättö, J., \& MattilaSandholm, T. (2000). Probiotic bacteria: safety, functional and technological properties. Journal of Biotechnology, 84(3), 197-215.

Schär-Zammaretti, P., \& Ubbink, J. (2003) The cell wall of lactic acid bacteria: surface constituents and macromolecular conformations. Biophysical Journal, 85(6), 4076-92.
Schillinger, U., Guigas, C., \& Holzapfel, W. H. (2005). In vitro adherence and other properties of lactobacilli used in probiotic yoghurt-like products. International Dairy Journal, 15, 1289-1297.

Sekirov, I., Russell, S. L., Antunes, C. L., \& Finlay, B., (2010). Gut Microbiota in Health and Disease. Physiological Reviews, 90, 859-904.

Sengupta, R., Altermann, E., Anderson, R. C., McNabb, W. C., Moughan, P. J., \& Roy, N. C. (2013). The role of cell surface architecture of lactobacilli in host-microbe interactions in the gastrointestinal tract. Mediators of inflammation, 2013, 237921.

Wadström, T., Andersson, K., Sydow, M., Axelsson, L., Lindgren, S., \& Gullmar, B. (1987). Surface properties of lactobacilli isolated from the small intestine of pigs. Journal of Applied Bacteriology, 62, 513-520. 